\title{
EFFECT OF ACID \& IODINE VALUE OF KARANJA OIL METHYL ESTER (KOME) \& ITS STATISTICAL CORRELATION WITH GROSS CALORIFIC VALUE
}

\author{
Sayyed Siraj $\mathbf{R}^{1}$, Leena Uttarwar ${ }^{2}$, Sheetal Pagey ${ }^{3}$, Rashmi Suryawanshi ${ }^{4}$ \\ ${ }^{1}$ Mechanical Engineering Dept., ${ }^{2,3,4}$ Applied Science \& Humanities Dept., Maharashtra Institute of Technology, \\ Aurangabad, lucky.sartaj@gmail.com
}

\begin{abstract}
Due to increasing popularity of Biodiesel in the world each and every property is important while designing an Engine.

Biodiesel is basically Fatty Acid methyl ester based fuel, a long chain of triglycerides and the alcohol in the presence of catalyst forms ethyl esters and the glycerol that process is known as Transesterification, if the free fatty acid content percentage in the oil is more than $2.5 \%$ then the process by which the oil is converted to ethyl esters is known as Esterification followed by Transesterification.

In this study we mostly concentrate on the Chemical properties; The Chemical properties like Acid Value, Iodine Value are having statistical correlations with the Gross Calorific Value of Karanja Oil Methyl Ester (KOME). We have also shown in the paper, the individual properties have how much percent statistical correlation with the gross calorific value, we have calculated it by Least square Approximation of Linear Regression.
\end{abstract}

Keywords: Biodiesel, Transesterification, Esterification, Characterization of Biodiesel.

$* * *$

\section{INTRODUCTION:}

Now a day's Energy crises is one of the important issue for us, fossil diesel has utilized everywhere in the world for the production process of the industry, Transportation sectors and also used in ships, motor vehicles, Etc. but the emission produced by that fossil diesel after burning is very ineffective for our health and also for climate, it increases air pollution and the global warming. Fossil diesel contributes almost $80 \%$ of the world's energy needs $[1,2,3]$.

Most of the country in the world that are agricultural, due to fluctuating global prices of the crude oil has an adverse impact on economy of many nations especially oil importing countries, apart from the fossil diesel is non - renewable source of energy, due to the depletion of fossil diesel fuels, the prices are also increasing day by day ultimately it leads to the economic recession in the various developing countries.If we see the previous data the diesel consumption itself in India 2008 - 2009 was 51.7 million Tons and 159.7 million Tons of $\mathrm{CO}_{2}$ was likely to be generated by such usage of fossil diesel [4].

Basically, Karanja is a medium sized fast - growing evergreen tree, which reaches 40 feet in height and spread, forming a broad, spreading canopy casting moderate shade showing in
Photo 1 . The time needed by the tree to mature ranges from 4 to 7 years and depending on the size of the tree the yield of kernels per tree is between 8 to $24 \mathrm{~kg}$ and the yield of potential per hectare is 900 to $9000 \mathrm{~kg} /$ hectare [4].

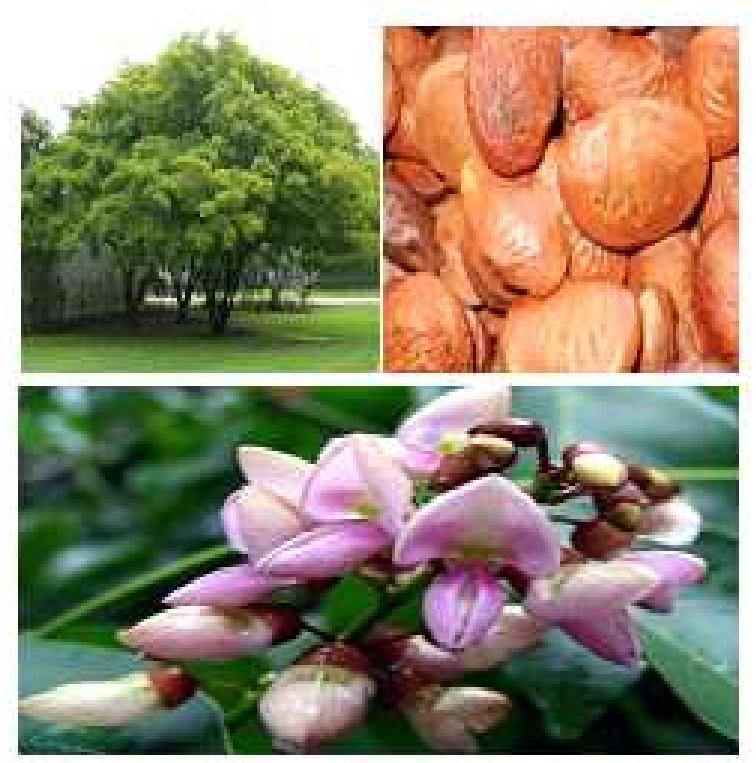


The plant is also said to be highly tolerant and salinity and can be grown in various soil textures viz. stony, sandy and clayey, it can also grow in humid as well as subtropical environments with annual rainfall ranging between 500 to $2500 \mathrm{~mm}[2,4]$.

Most of the researchers have put the statement this tree is having oil content 30 to $33 \%$ or 30 to $40 \%$. It is one of the few nitrogen fixing tree. This spice is commonly called Pongam, Karanja, pongamia, or a derivation of these names. Flowers are pink, light purple or white showing in photo 3 . Pods are elliptical, 3 to $6 \mathrm{~cm}$ long and 2 to $3 \mathrm{~cm}$ wide, thick walled and usually contain a single seed. Seeds are 10 to 20 $\mathrm{mm}$ long, fig oblong and light brown colour showing in photo 2 [4].

In its natural habitat, the maximum temperature ranges of maximum from $27-38^{\circ} \mathrm{C}$ and minimum $1-16^{\circ} \mathrm{C}$. Mature trees can withstand water logging and slight forest. Air - dried karanja kernels have typically 19\% Moisture, 27.5\% Fatty Oil, 17.4\% Protein, 6.6\% Starch, 7.3\% Crude Fiber and 2.4\% Ash. The oil is used by common people due to its low cost and easy availability $[2,4]$. The fatty acids composition of karanja oil has been reported in Table 1:

Table 1: Fatty Acid Composition of Karanja Oil [4].

\begin{tabular}{|c|c|c|c|}
\hline Fatty Acids & Formula & Structure & Weight in \% \\
\hline Palmitic & $\mathrm{C}_{16} \mathrm{H}_{32} \mathrm{O}_{2}$ & $16: 0$ & $3.7-7.9$ \\
\hline Stearic & $\mathrm{C}_{18} \mathrm{H}_{36} \mathrm{O}_{2}$ & $18: 0$ & $2.4-8.9$ \\
\hline Lignoceric & $\mathrm{C}_{20} \mathrm{H}_{40} \mathrm{O}_{2}$ & $24: 0$ & $1.1-3.5$ \\
\hline Oleic & $\mathrm{C}_{18} \mathrm{H}_{34} \mathrm{O}_{2}$ & $18: 1$ & $44.5-71.3$ \\
\hline Linoleic & $\mathrm{C}_{18} \mathrm{H}_{32} \mathrm{O}_{2}$ & $18: 2$ & $10.8-18.3$ \\
\hline
\end{tabular}

Photo 1: Karanja Tree Photo 2: Karanja Seeds Photo 3: Flowers of Karanja

The Equations were developed for the calculations of the Gross Calorific Value of Karanja Oil Methyl Esters from Acid Value and Iodine Value.

The Equations between Acid Value and the Gross Calorific Values are for Karanja Oil Methyl Esters.

Gross Calorific Value $(\boldsymbol{k J} / \mathbf{k g})=45.4-0.671 \times$ Acid Value $(m g \mathrm{KOH} / \mathrm{g})_{\ldots} \ldots \quad(1)$

Then after that, we were developed the Equations between Iodine Value and Gross Calorific Value are for Karanja Oil Methyl Esters.

Gross Calorific Value $(\boldsymbol{k J} / \mathbf{k g})=45.4-0.0993 \times$ Iodine Value .... (2)
Then after that, we were developed the Equations between Acid Value and Iodine Value and Gross Calorific Value are for Karanja Oil Methyl Esters.

Gross Calorific Value $(\mathbf{k J} / \mathbf{k g})=45.4-0.033 \times$ Acid Value $0.0945 x$ Iodine Value

\section{MATERIAL \& METHODS:}

\subsection{Acid Value:}

The term Acid Value is defined as the number of milligrams of potassium hydroxide required to neutralize the free fatty acids (FFA) present in one gram of oil or fat. It is relative measure of rancidity as free fatty acids are normally formed during decomposition of oil glycerides. The value is also expressed as percent of free fatty acids calculated as Oleic acid [7].

As per the ASTM D6751 standard, the Acid value of oil or fat can be measured by D664 standard and as per European EN 14214 Standard, the Acid Value of oil or fat can be measured by pr EN 14104 standard. The maximum limit I given for Acid Value 0.80 max as per ASTM D6751 and 0.50 max as per EN 14214 standards. The unit is used for Acid Value mg KOH/g [5].

The Acid Value is determined by directly titrating the oil or fat in an alcoholic medium against standard potassium hydroxide or sodium hydroxide solution, most of the researchers have used these principle while determining the Acid Value of oil of fat [6].

In this research work we have taken the karanja oil methyl esters and its blends in the step of 10 i. e. B00 (Neat Diesel), B10, B20, B30, B40 upto B100 (Neat Biodiesel). As the biodiesel percentage increases in the blends simultaneously the Acid Value of Blends also increases and vice - versa. The below graph 1 is showing how the Acid Value of Karanja Oil Methyl Ester blends increases as the percentage of fossil diesel decreases.

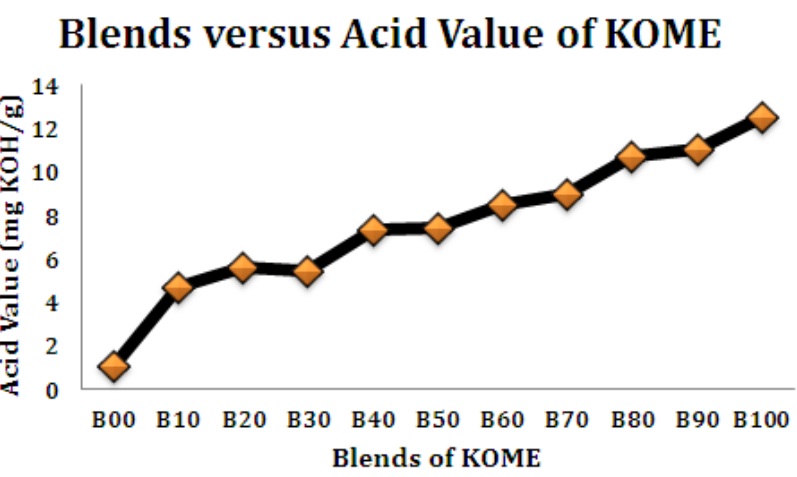

Graph 1 


\subsection{Iodine Value:}

The Iodine Value of an oil or fat is defined as the amount of Iodine grams which reacts with 100 grams of the oils or fat. The Iodine Value is a measure of the unsaturation of fats and oils and hence their potential to become oxidized. The oil is treated with an excess of Iodine Monochloride in solution in acetic acid. The amount of Iodine absorbed is determined by back - titration with standard sodium thiosulfate solution. The Iodine Value indicates the drying quality of oil, the drying oils having higher Iodine Values. The Iodine Value is of real significance in the examination of fatty oils since most fatty oils have their own characteristic iodine Value [8].

As per ASTM D6751 standard, the Iodine Value of oil or fat do not have any standard method for measurement and do not have any specific unit for it but in European EN 14214 standard is having provision for measurement of Iodine Value by pr EN 14111 standard. As per the EN standard the limit is given for Iodine Value 120 max [5].

In this research work we have taken the karanja oil methyl esters and its blends in the step of 10 i. e. B00 (Neat Diesel), B10, B20, B30, B40 upto B100 (Neat Biodiesel). As the biodiesel percentage increases in the blends simultaneously the Iodine Value of Blends also increases and vice - versa. The below graph 2 is showing how the Iodine Value of Karanja Oil Methyl Ester blends increases as the percentage of fossil diesel decreases.

\section{Blends versus Iodine Value of KOME}

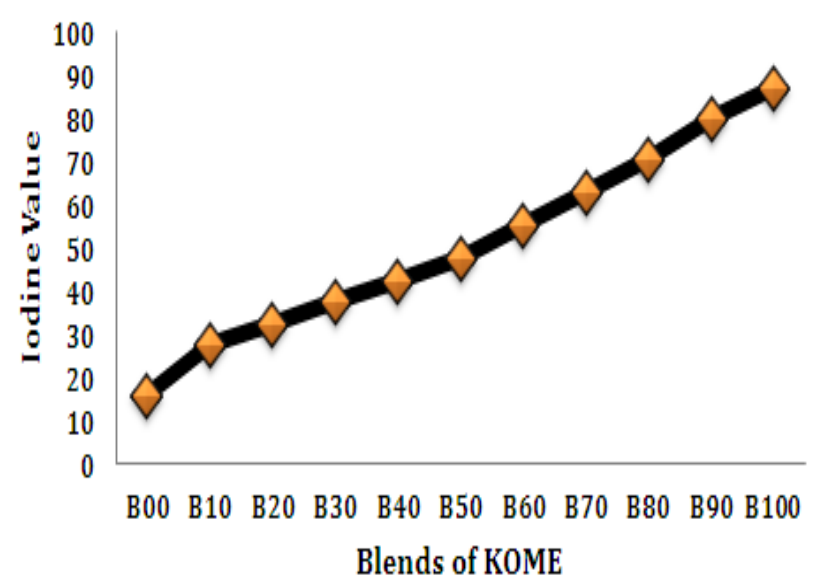

Graph 2

\subsection{Gross Calorific Value:}

The lower (LHV) and the higher (HHV) heating values are measures of a fuel's heat of combustion, with the difference between them being the water's heat of vaporization. Biodiesel contains on average $10-12 \%$ w/w oxygen, which leads to proportionally lower energy density and heating value, thus more fuel needs to be injected in order to achieve the same engine power output. Some of the Researchers have measured the Heating Value of the biodiesel, and their blends can be measure by ASTM Standard D 240 or as per DIN Standard of DIN 51900, DIN 51900-1, and DIN 51900-2, DIN 51900-3test methods [3, 5]. We have used Bomb Calorimeter Apparatus in the measurement of Heating Value but there is no specification as regards the biodiesel heating value, neither in the EU nor in the US. The Karanja biodiesel blends Gross Heating Value decreases as the fossil diesel percentage decreases or the biodiesel percentage increases in the blends. For Gross Calorific Value we have taken here blends in the step of 10, like B00 (Neat Fossil Diesel), B10, B20, B30, B40, B50, B60, B70, B80, B90, B100 (Neat Biodiesel).

The below graph 3 is showing how the Gross Calorific Value of Karanja oil Methyl Ester blends decreases as the percentage of fossil diesel decreases or the percentage of biodiesel increases in the blends.

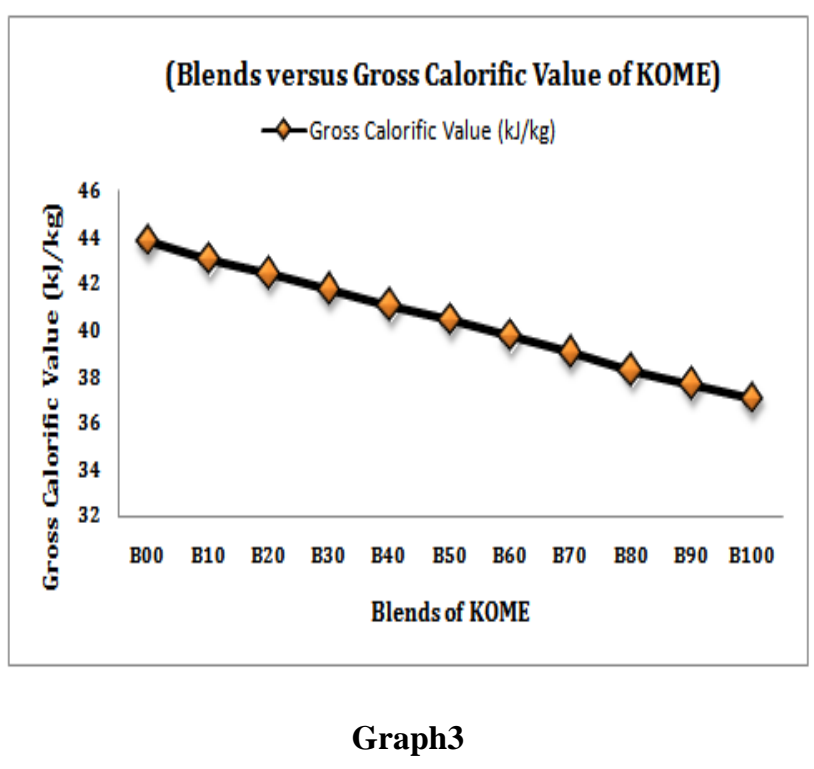

\section{RESULT \& DISCUSSIONS:}

\subsection{Acid Value versus Gross Calorific Value}

Acid Value versus Gross Calorific Value graph is showing below; In this graph we have seen that as the Acid Value of Karanja Oil Methyl Esters blends Increases simultaneously the Gross Calorific Value of Blends decreases. When fatty acids are present or in case of used oils, the acid value content should be determined not because it gives any direct evidence of corrosion hazard, but to sound warning that a corrosion test might be revealing. The acid value of good oil must be less than 0.1. Increase in Acid Value should be taken as indicator of oxidation of the oil which may lead to gum and sludge formation besides corrosion. 
The Acid Value of fatty oils may vary from 0.2 to 50 and it shows the extent of hydrolysis of glycerol ester of the oil. The below table 2 shows the Expected Acid Value from the mass of the oil or fat has to be taken for test.

Table 2: Expected Acid Value from Mass of Oil.

\begin{tabular}{|l|l|l|}
\hline $\begin{array}{l}\text { Expected } \\
\text { Acid Value }\end{array}$ & $\begin{array}{l}\text { Mass of } \\
\text { Test } \\
\text { Portion }\end{array}$ & $\begin{array}{l}\text { Accuracy } \\
\text { Weighing } \\
\text { Machine }\end{array}$ \\
\hline$<1$ & $20 \mathrm{~g}$ & $0.05 \mathrm{~g}$ \\
\hline 1 to 4 & $10 \mathrm{~g}$ & $0.02 \mathrm{~g}$ \\
\hline 4 to 15 & $2.5 \mathrm{~g}$ & $0.01 \mathrm{~g}$ \\
\hline 15 to 75 & $0.5 \mathrm{~g}$ & $0.001 \mathrm{~g}$ \\
\hline$>75$ & $0.1 \mathrm{~g}$ & $0.0002 \mathrm{~g}$ \\
\hline
\end{tabular}

Measured Acid Value versus Measured Gross Calorific Value

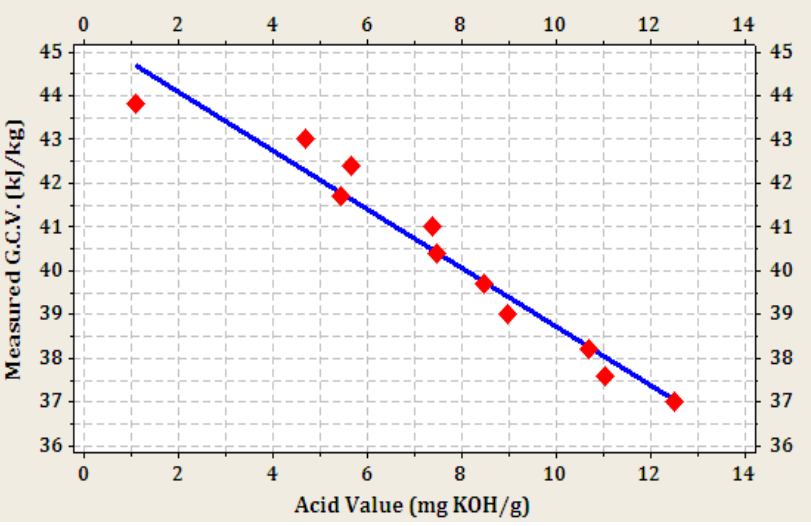

Graph 4

\subsection{Iodine Value versus Gross Calorific Value:}

Iodine Value versus Gross Calorific Value graph is showing below; In this graph we have seen that as the Iodine Value of Karanja Oil Methyl Esters blends Increases simultaneously the Gross Calorific Value of Blends decreases. Iodine Value is intended as a measure of unsaturation and at times it is used as a quick alternative to oxidation tests of mineral oils. Iodine Value indicates the drying quality of oil, the drying oils having higher Iodine Values.

Iodine Value is of real significance in the examination of fatty oils since most fatty oils have their own characteristic Iodine Values. Solid fats possess Iodine Value less than 50 whereas drying oils possess Iodine Values more than 140 while the Iodine Value of non - drying and semidrying oils range from 50 to 140

\section{Iodine Value versus Measured Gross Calorific Value}

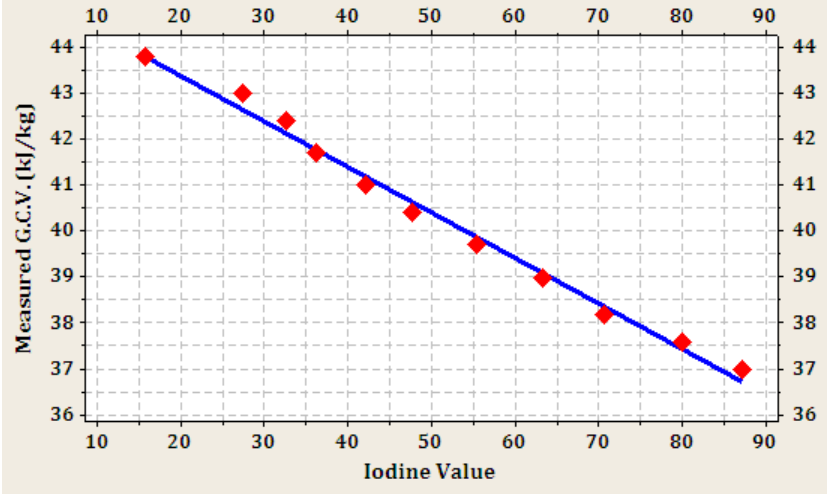

Graph 5

The iodine Value of fatty acids may vary from various ranges and it may vary according to the various mass of oil or fats. Some of the values are given in table from which we have taken in the consideration from the mass of oil or fats.

Table 3: Expected Iodine Value from Mass of Oil [6].

\begin{tabular}{|l|l|l|}
\hline $\begin{array}{l}\text { Expected Iodine } \\
\text { Value }\end{array}$ & $\begin{array}{l}\text { Max. Weight of } \\
\text { Test Portion }\end{array}$ & $\begin{array}{l}\text { Min. Weight of } \\
\text { Test Portion }\end{array}$ \\
\hline 5 & 6.3460 & 5.0770 \\
\hline 10 & 3.1730 & 2.5384 \\
\hline 50 & 0.6612 & 0.5288 \\
\hline 100 & 0.3173 & 0.2538 \\
\hline 150 & 0.2125 & 0.1700 \\
\hline 200 & 0.1586 & 0.1269 \\
\hline
\end{tabular}

Table 4: Expected Iodine Value from Mass of Oil $[9,10]$.

\begin{tabular}{|l|l|}
\hline Iodine Value Range & Oil Sample in $(\mathrm{g})$ \\
\hline$<20$ & $1.0 \mathrm{~g}$ \\
\hline 21 to 60 & 0.25 to $0.50 \mathrm{~g}$ \\
\hline 61 to 100 & 0.15 to $0.25 \mathrm{~g}$ \\
\hline$>100$ & 0.10 to $0.15 \mathrm{~g}$ \\
\hline
\end{tabular}

\section{CONCLUSIONS}

\subsection{Statistical Correlation between Acid Value\&}

\section{Gross Calorific Value:}

The below given equation gives the statistical correlation between the Acid Value\& the gross calorific Value of Karanja Oil Methyl Ester,

$$
\begin{gathered}
\text { Gross Calorific Value }(\mathrm{kJ} / \mathrm{kg})=45.4-0.671 \times \text { Acid Value } \\
(\mathrm{mg} \mathrm{KOH} / \mathrm{g})
\end{gathered}
$$

There is a strong statistical correlation between Acid Value\& the Gross Calorific Value because after the statistical analysis R2 shows the value $95.10 \%$ only, it means that the Acid 
Value\& Gross Calorific Value have $95.10 \%$ Correlation between them. By this correlation we have Calculated Gross Calorific Value and have shown Calculated Gross Calorific Value versus Measured Gross Calorific values on the graph.

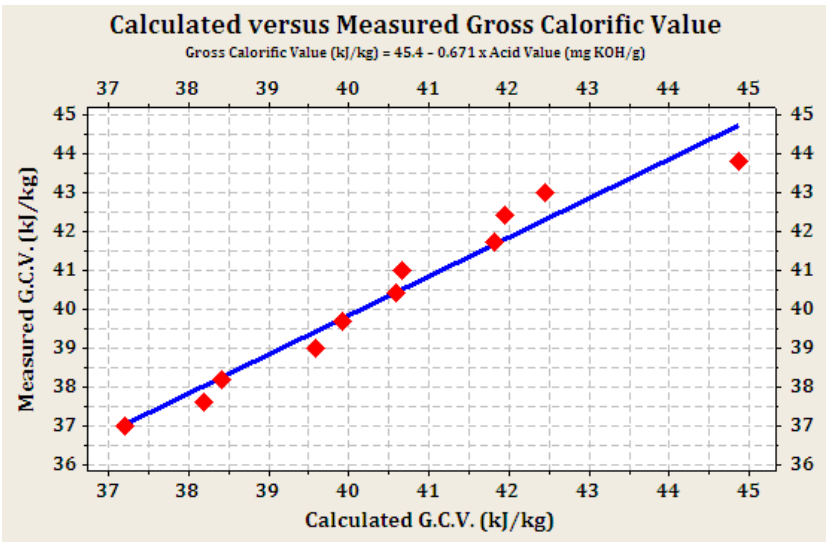

Graph 6

\subsection{Statistical Correlation between Iodine Value \&}

\section{Gross Calorific Value:}

The below given equation gives the statistical correlation between the Iodine Value \& the gross calorific Value of Karanja Oil Methyl Ester,

Gross Calorific Value $(\mathrm{kJ} / \mathrm{kg})=45.4-0.0993 \times$ Iodine Value (Equation 2)

There is a strong statistical correlation between Acid Value \& the Gross Calorific Value because after the statistical analysis R2 shows the value $99.10 \%$ only, it means that the Iodine Value \& Gross Calorific Value have $99.10 \%$ Correlation between them. By this correlation we have Calculated Gross Calorific Value and have shown Calculated Gross Calorific Value versus Measured Gross Calorific values on the graph.

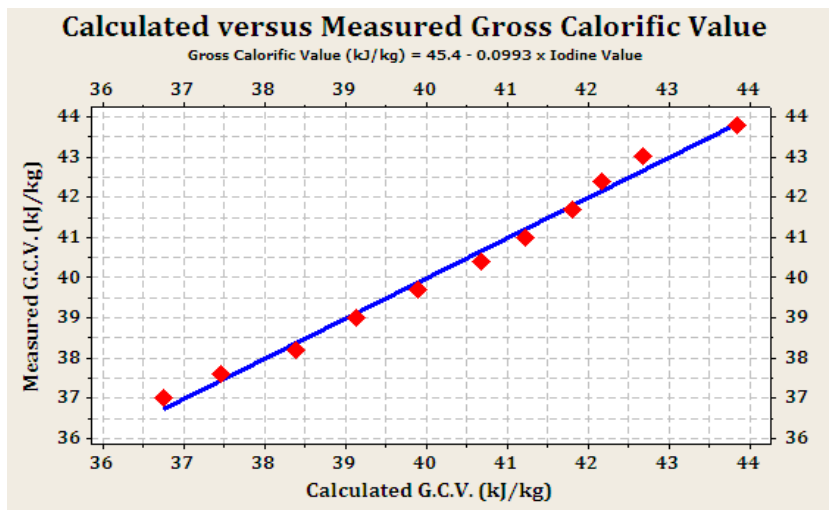

Graph 7

\subsection{Statistical Correlation between Acid Value, Iodine Value \& Gross Calorific Value:}

The below given equation gives the statistical correlation between the Acid Value, Iodine Value \& the gross calorific Value of Karanja Oil Methyl Ester,

\section{Gross Calorific Value $(\mathrm{kJ} / \mathrm{kg})=45.4-0.033 \times$ Acid Value - $0.0945 \times$ Iodine Value $\quad$.... (Equation 3)}

There is a strong statistical correlation between Acid Value, Iodine Value\& the Gross Calorific Value because after the statistical analysis R2 shows the value $99.10 \%$ only, it means that the Acid Value, Iodine Value \& Gross Calorific Value have $99.10 \%$ Correlation between them. By this correlation we have Calculated Gross Calorific Value and have shown Calculated Gross Calorific Value versus Measured Gross Calorific values on the graph.

\section{Calculated versus Measured Gross Calorific Value} Gross Calorific Value $(\mathrm{kJ} / \mathrm{kg})=45.4 \cdot 0.033 \times$ Acid Value $\cdot 0.0945 \times$ lodine Valu

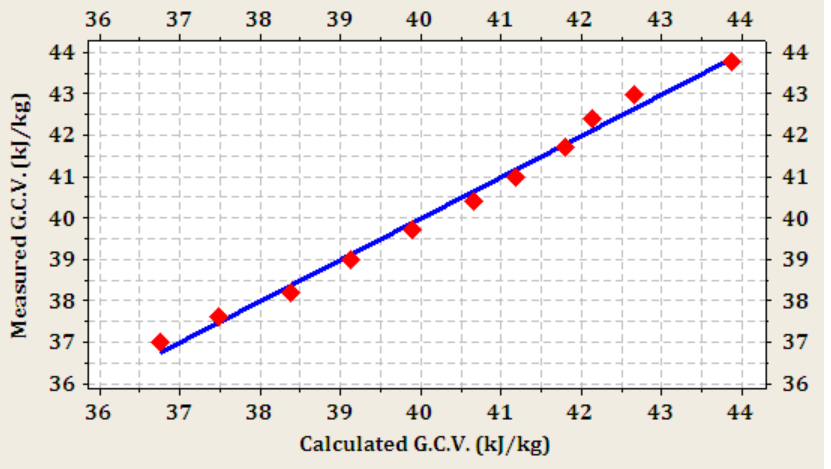

\section{Graph 8}

At last we can conclude that,

i. The Acid Value individually is having $95.10 \%$ statistical correlation with the Gross Calorific Value, because of this accuracy we will get most accurate Gross Calorific Value of Karanja oil Methyl Ester from the given relation and it is the most important property in the calculation.

ii. At the same time we have seen the relation between Iodine Value and the Gross Calorific Value; in this relation we got the individual property Iodine Value having $99.10 \%$ statistical correlation with the Gross Calorific Value of Karanja Oil Methyl Ester. Because of this accuracy this property deserves its position in the calculation.

iii. Future Scope of this study, at last if we considered the more other physio - chemical properties in combination in the statistical analysis then and then only we will get most accurate results from the statistical Equations and it will definitely help in the 
calculation of engine combustion parameter designing in future.

\section{REFERENCES}

[1] K. Shivaramakrishnan and P. Ravikumar. Determination of Cetane Number of Biodiesel and its Influence on Physical Properties. Arpan Journals of Engineering and Applied Sciences. 2012; 2: 205 - 211.

[2] K. Anand, R.P. Sharma, Pramod S. Mehta. A Comprehensive Approach for Estimating Thermo Physical Properties of Biodiesel Fuels. Applied Thermal Engineering. 2011; 31: 235 - 242.

[3] K. Shivaramakrishnan and P. Ravikumar. Determination of Higher Heating Value of Biodiesels. International Journal of Engineering Science and Technology (IJEST). 2011; 3: (11) 7981 - 7987.

[4] Avinash Kumar Agarwal, K. Rajamanoharan. Experimental Investigations of Performance and emissions of Karanja oil and Blends in a Single Cylinder Agricultural Diesel Engines. Applied Energy. 2009; 86: 106 - 112.

[5] National Renewable energy Laboratory (NREL) Innovation for Our Energy Future. Biodiesel Handling and Use Guide Fourth Edition. Revised January 2009; NREL/TP - 540 - 43672.

[6] FSSAI - Manual of Methods of Analysis of Foods (Oil \& Fats); 2012.

[7] Dr. S. S. Dara, Determination of Acid Value of Lubricating Oil, A Text Book on Experiments and Calculations in Engineering Chemistry, S. Chand Publication - ISBN: 81-219-0864-7, Code: 04048.

[8] Dr. S. S. Dara, Determination of Iodine Value of Lubricating Oil, A Text Book on Experiments and Calculations in Engineering Chemistry, S. Chand Publication - ISBN: 81-219-0864-7, Code: 04048.

[9] Fish oil Bulletin: IAFMM - International Association of Fish Meal Manufacturers; 4/June/1981.

[10] IP: 2007, Manual of Indian Pharmacopoeia 2007. 